\title{
Nilai-Nilai Pendidikan Karakter pada Film Adit dan Sopo Jarwo Ditinjau dari Aspek Pedagogik
}

\author{
Francisca Sutiyani ${ }^{1} \bowtie$, Tuti Tarwiyah Adi ${ }^{2}$, R. Sri Martini Meilanie ${ }^{3}$ \\ Pendidikan Anak Usia Dini, Universitas Negeri Jakarta \\ DOI: $\underline{10.31004 / o b s e s i . v 5 i 2.1133}$
}

\begin{abstract}
Abstrak
Karakter erat kaitannya dengan nilai-nilai kebajikan yang mesti dibiasakan agar terbentuk suatu pola dalam pribadi individu yang masih ada tatanan dalam masyarakat untuk berpikir dan bertindak sesuai dengan nilai-nilai yang diutamakan dalam masyarakat. Penelitian ini bertujuan untuk mendeskripsikan nilai-nilai karakter apa yang ditanamkan dalam film Adit dan Sopo Jarwo dan Menganalisis relevansi film Adit dan Sopo Jarwo dalam menanamkan nilai-nilai karakter jika ditinjau dari aspek sosiopedagogiek. Penelitian ini menggunakan metode kualitatif dengan menggunakan metode analisis konten. Hasil penelitian dapat disimpulkan bahwa film Adit dan Sopo Jarwo mengandung nilai-nilai karakter jika ditinjau dari aspek pedagogies diantaranya nilai karakter menjaga hubungan dengan Tuhan dan sesama yang didalamnya terkandung sifat sopan santun, jujur, saling menghormati, saling menyayangi dan disiplin.
\end{abstract}

Kata Kunci: pendidikan karakter; pedagogik; anak usia dini

\begin{abstract}
Character is closely related to the values of virtue that must be accustomed to form a pattern in the individual person that still has an order in society to think and act in accordance with the values that are prioritized in society. This study aims to describe what character values are implanted in the Adit and Sopo Jarwo films and to analyze the relevance of Adit and Sopo Jarwo's films in instilling character values when viewed from the sociopedagogical aspect. This study uses qualitative methods using content analysis methods. From the research results, it can be concluded that the film Adit and Sopo Jarwo contains character values when viewed from the pedagogical aspect, including the character value of maintaining a relationship with God and others which includes polite, honest, mutual respect, mutual love and discipline.
\end{abstract}

Keywords: character education; pedagogical; early childhood

Copyright (c) 2021 Francisca Sutiyani, Tuti Tarwiyah Adi, R. Sri Martini Meilanie

$\square$ Corresponding author :

Email Address : franciscastyn@gmail.com ( Jakarta, Indonesia )

Received 7 February 2021, Accepted 21 February 2021, Published 6 March 2021 


\section{PENDAHULUAN}

Masa anak usia dini adalah masa yang tepat untuk menanamkan pendidikan karakter. Pendidikan karakter adalah pendidikan nilai, pendidikan budi pekerti, pendidikan moral, pendidikan watak yang bertujuan mengembangkan kemampuan peserta didik untuk memberikan keputusan baik maupun buruk (Nyoman, 2003). Membangun karakter anak merupakan salah satu hal yang sangat diperhatikan oleh pemerintah sehingga sudah sepatutnya disambut baik dan dirumuskan langkah-langkah yang sistematis dan komprehensif untuk implementasinya dalam proses pendidikan. Karakter bangsa sangat tergantung pada kualitas karakter sumber daya manusianya (SDM), karenanya karakter yang berkualitas perlu dibentuk dan dibina sejak usia dini.

Aspek yang dikembangkan dalam Pendidikan Anak Usia Dini meliputi program pengembangan Nilai-nilai Agama dan Moral, Sosial emosi, Fisik Motorik, Kognitif, Bahasa dan Seni. Hal ini juga dipertegas oleh (Samani \& Hariyanto, 2011) yang menyatakan bahwa bangsa ini harus dibangun dengan membangun dengan mendahulukan pembangunan karakter (character building) karena character building inilah yang akan membuat Indonesia menjadi bangsa yang besar, maju dan jaya serta bermartabat. Kalau character building ini tidak dilakukan, maka bangsa Indonesia akan menjadi bangsa kuli.

Dalam upaya mengembangkan pribadi peserta didik menjadi utuh, maka diperlukan adanya penanaman nilai-nilai melalui pendidikan karakter. Pendidikan karakter di masa kini telah menjadi fokus dalam pendidikan di Indonesia. Pendidikan karakter merupakan jantung dari kurikulum pendidikan anak usia dini (PAUD). Pendidikan karakter sebagai dasar membangun kesehatan mental dan motivasi untuk belajar. Pendidikan karakter bertujuan untuk menanamkan sikap positif pada anak sejak usia dini melalui pembiasaaan sehingga tumbuh menjadi pribadi yang berperilaku baik (Nuraeni, 2014). Pendidikan karakter bukan sekedar membiasakan anak berperilaku baik, tetapi lebih dari itu, yakni membentuk pikiran, watak dan berperilaku yang baik (Devianti et al., 2020). Hal ini dilakukan untuk mempersiapkan generasi yang berkualitas. Pendidikan Karakter menjadi suatu keharusan karena pendidikan karakter tidak hanya menjadikan anak menjadi cerdas secara akademik saja, melainkan juga menjadikan anak memiliki budi pekerti dan sopan santun.

Karakter merupakan salah satu aspek kebutuhan sekaligus output proses pendidikan di mana proses pembelajarannya menekankan pada penanamanan nilai- nilai hidup. Pembentukan karakter merupakan suatu upaya yang mudah dan cepat, namun perlu proses yang cukup rutin dan terus menerus. Dalam hal ini memerlukan sinergi yang baik antar sekolah, keluarga, masyarakat. Pendidikan karakter tanggung jawab tiga pusat pendidikan yaitu lingkungan keluarga, lingkungan sekolah dan lingkungan masyarakat. Keluarga merupakan lingkungan pendidikan pertama yang menanamankan, menguatkan serta mengembangkan karakter dasar seorang anak yang telah dibentuk di dalam keluarga. Terakhir lingkungan masyarakat yang merupakan tempat interaksi antar individu serta penerapan nilai dan norma juga harus bersinergi untuk mencapai keberhasilan pendidikan karakter (Agung \& Asmira, 2018). Pendidikan karakter pada anak usia dini ini memerlukan adanya kolaborasi antara keluarga, sekolah dan masyarakat yang baik. Di mana setiap fungsi saling menguatkan dan saling melengkapi. Menurut Lickhona, karakter yang baik adalah terdiri dari mengetahui hal yang baik, menginginkan hal yang baik, dan melakukan hal yang baik serta kebiasaan dalam cara berpikir, kebiasaan dalam hati, dan kebiasaan dalam tindakan. Ketiga hal ini diperlukan untuk mengarahkan suatu kehidupan moral; ketiganya ini membentuk kedewasaan moral (Thomas Lickona, 2012). Penanaman nilai-nilai karakter pada usia dini memerlukan suatu cara yang khusus, karena anak adalah pribadi yang unik. Hal ini memerlukan upaya yang terus menerus, konsisten, dan refleksi.

Karakter anak perlu dibangun sejak dini. Hal ini dikarenakan kehidupan anak tidak terlepas dari pergaulan dan pengaruh lingkungan dari berbagai media, sehingga anak-anak diharuskan lebih mendalami atau mengenal dirinya sendiri, agar memiliki pedoman dalam kehidupannya. Pengarahan karakter anak merupakan upaya agar anak masuk dalam rel-rel 
sikap yang positif. Ratna Megawangi juga menyatakan bahwa anak-anak akan tumbuh menjadi pribadi yang berkarakter apabila dapat tumbuh pada lingkungan yang berkarakter, sehingga setiap anak yang dilahirkan suci dapat berkembang secara optimal (Latifatul Masruroh, 2020). Hal ini memiliki makna bahwa lingkungan anak sangat menentukan tumbuh kembang anak dalam membentuk karakter anak. Jika lingkungan anak menunjukkan budaya yang baik, maka karakter anakpun akan berkembang baik pula.

Menurut Tafsir bahwa proses pengintegrasian pendidikan karakter dalam pembelajaran dapat dilakukan dengan beberapa cara, diantaranya: (a) pengintegrasian materi pelajaran (b) pengintegrasian proses (c) pengintegrasian dalam memilih bahan ajar (d) pengintegrasian dalam memilih media (Pratama, 2020).

Pendidikan karakter sudah lama menjadi isu dalam pendidikan. Berbagai hal dilakukan untuk membentuknya karakter anak oleh stimulus yang diberikan kepada anak. Pembentukan karakter ini disampaikan melalui pembelajaran pembiasaan, keteladanan maupun kegiatan yang terprogram. Salah satu contoh yang dapat dilakukan untuk mengembangkan karakter anak yakni melalui media. Media menjadi alternatif penyampaian pesan dalam pendidikan karakter. Media menjadi saluran komunikasi yang menjangkau publik yang berjumlah besar. Media massa secara sederhana terdiri dari media cetak (surat kabar, majalah, buku, dan lain-lain), media elektronik (televisi dan radio), dan media online. Berkat perkembangan teknologi informasi dan telekomunikasi, pengertian media massa ini makin meluas. Penulis di sini akan lebih berfokus pada media film. Film bukan sekedar media pandang dengar dan barang dagangan, melainkan juga berfungsi sebagai hiburan yang mengandung aspek-aspek pendidikan dan penerangan. Media film ini dapat menjadi salah satu sarana pembinaan bangsa dan pembangun watak.

Media massa efektif dalam setiap bidang kehidupan karena kekuatan audiovisualnya. Selain penggunaan bioskop untuk tujuan hiburan, peran pendidikannya telah terwujud; dan memanfaatkan ekspresi visual dalam pendidikan telah diperluas. Metode pendidikan nonkonvensional yang berkembang pesat dewasa ini memungkinkan menggunakan film pendek dalam pendidikan (Kabadayi, 2012). Film mempunyai keunggulan sebagaimana dikemukakan oleh Sukenti yaitu: merupakan suatu dominator belajar yang umum, sangat bagus untuk menerangkan suatu proses, dapat menyajikan baik teori maupun praktek, dapat mengikat perhatian anak, lebih realitis, dapat diulang-ulang, dihentikan dan sebagainya, sesuai dengan kebutuhan, mengatasi keterbatasan daya indera kita (penglihatan) film dapat merangsang atau memotivasi kegiatan anak-anak (Sukenti, 2011). Film merupakan media yang amat besar kemampuannya dalam membantu proses belajar mengajar (Sadiman \& Dkk, 1990).

Dewasa ini banyak serial kartun yang ditayangkan di televisi dan disukai anak-anak. Namun tidak semua serial kartun pantas untuk disaksikan oleh anak-anak karena banyak film kartun yang menampilkan adegan-adegan kekerasan, pornografi yang tidak layak untuk dikonsumsi oleh anak-anak. Dunia film terutama animasi baik dua dimensi maupun tiga dimensi mulai dari zaman dulu sampai sekarang tidak bisa lepas dari anak-anak karena penayangannya yang setiap hari dan selalu berhasil menyita perhatian anak-anak. Film animasi digemari oleh anak-anak mulai dari usia tiga tahun yang mana masih belum terlalu lancar melafalkan kalimat-kalimat pendek dan belum bisa memahami maksud dari cerita dalam film animasi tersebut. Anak-anak cenderung lebih tertarik pada grafis dari film animasi tersebut (Khakim \& Sofiana, 2019).

Diantara film animasi yang beredar di televisi dan digemari oleh anak-anak di Indonesia salah satunya yang paling populer ialah Upin-Ipin dan Spongebob Squarepants dan film Adit dan Sopo Jarwo. Upin-Ipin merupakan film animasi Malaysia. Animasi tersebut bercerita tentang kehidupan dari anak kembar yatim piatu yang tinggal bersama nenek dan kakaknya. Animasi selanjutnya yaitu Spongebob yang merupakan film animasi Amerika Serikat. Animasi tersebut bercerita tentang kehidupan sebuah spons laut dan kehidupan biota laut lainnya yang dikemas dengan humor. Selain melalui media televisi, ada pula film animasi 
yang dimuat dalam media youtube salah satunya yaitu Nussa dan Rara. Animasi karya anak bangsa yang menceritakan tentang kehidupan seorang adik kakak. Animasi tersebut membawakan tema religius yang kental mengenai adab dan perilaku seorang muslim Seperti salah satu film animasi yang diproduksi oleh Les Copaque "Upin dan Ipin" yang setiap harinya ditayangkan di MNC TV dapat menarik perhatian khususnya anak-anak. (Khakim \& Sofiana, 2019)

Patricia Mars Greenfield dalam bukunya Mind and Media, yang telah diterjemahkan oleh Sugeng P, bahwa "Menonton televisi dapat menjadi suatu kegiatan pasif yang mematikan apabila orang tuanya tidak mengarahkan apa-apa yang boleh dilihat oleh anak-anak mereka, sekaligus mengajar anak-anak itu untuk menonton secara kritis serta untuk belajar dari apa yang mereka tonton" (Zhayoga et al., 2020). Anak banyak belajar dari apa yang mereka lihat dan saksikan secara langsung. Mereka banyak meniru dari apa yang mereka lihat sebagai sebuah pengalaman belajar.

Film animasi Adit dan Sopo Jarwo merupakan film karya anak dalam negeri dan tanpa campur tangan orang asing. Dalam film ini, terdapat pesan-pesan yang bisa dijadikan pelajaran, terkhusus bagi anak-anak. Dalam film ini diceritakan tentang petualangan seorang anak kecil yang bernama Adit bersama teman-temannya. Dalam film ini juga diceritakan dua orang yang selalu mencari keuntungan di balik setiap permasalahan. Namun, disetiap permasalahan yang muncul selalu ada ketua RW yaitu Haji Udin yang selalu memberikan nasehat dan masukan dari setiap permasalahan. Film animasi Adit, Sopo, dan Jarwo menjadi objek penelitian karena kisah yang terdapat dalam film ini sangat menggambarkan tentang realitas sosial masyarakat pada umumnya. Film ini menampilkan permasalahanpermasalahan yang sering terjadi di masyarakat. Selain menayangkan problem yang terjadi di masyarakat, film ini juga memberikan solusi bagaimana mengatasi permasalahan tersebut. Penulis tertarik untuk mengkaji lebih mendalam nilai-nilai karakter yang ada dalam film Sopo Jarwo ditinjau dari aspek sosiopedagogiek.

Film Adit dan Sopo Jarwo telah banyak dikaji sebelum-sebelumnya namun yang membedakan antara penelitian yang akan penulis tulis fokus pada tinjauan konten nilai-nilai karakter dari aspek sosiopadagogiek.

\section{METODOLOGI}

Pedekatan penelitian yang digunakan oleh peneliti adalah pendekatan kualitatif. Pendekatan kualitatif merupakan pendekatan penelitian yang digunakan untuk meneliti gejala sosial secara alamiah tanpa adanya tindakan untuk mempengaruhi kealamiahan objek serta mendapatkan data yang mendalam dan menekankan pada makna (Sugiyono, 2007). Metode penelitian yang digunakan oleh peneliti adalah metode analisis konten (content analysis).

Adapun teknik analisis konten dapat diterapkan untuk menganalisis esai, lagu, pidato, iklan, artikel majalah, artikel koran, gambar, komik, buku teks, buku memasak, dan media komunikasi lainnya. Tahap pertama dalam penelitian analisis konten adalah determine objectives yaitu menentukan tujuan mengapa peneliti menggunakan metode analisis konten baik untuk mendeskripsikan sebuah informasi, memecahkan masalah dalam pendidikan, mengecek penelitian peneliti lain, dan lain sebagainya. Relasi dari analisa konten dalam film Adit dan Sopo Jarwo. Tahap kedua adalah define terms yaitu mendefinisikan istilah yang ditemukan peneliti dalam metode penelitian analisis konten agar memudahkan peneliti dalam melakukan penelitian. Menerapkan metode yang tepat untuk mengklasifikasikan karakter dalam film Adit dan Sopo Jarwo.

Tahap ketiga adalah specify the unit of analysis yaitu menentukkan unit analisis apa yang akan diteliti di antaranya unsur-unsur intrinsik, frasa, paragraf, kalimat, dan lain sebagainya. Pada tahap ini akan dianalisa dari setiap kalimat yang diucapkan tokoh-tokoh dalam Adit dan Sopo Jarwo. Tahap keempat adalah locate relevant data yaitu mencari data yang relevan dengan mencari sumber data sesuai unit analisis yang dipilih seperti bersumber dari majalah, buku, 
koran, televisi, dan lain sebagainya. Tahap kelima adalah develop a rationale yaitu menentukkan dasar pikiran menggunakan konsep dan teori dari para ahli berkaitan dengan data atau unit yang dianalisis.

Tahap keenam adalah develop a sampling plan yaitu mengembangkan rencana pengambilan sampel atau menentukan cara peneliti mengambil sampel data. Tahap ketujuh adalah formulate coding categories yaitu merumuskan kategori coding atau kategori yang akan dianalisis dari unit analisis yang telah ditentukkan seperti unit unsur intrinsik komik memiliki kategori tema, bahasa dan gambar, penokohan, dan lain sebagainya. Tahap kedelapan adalah check reliability and validity yaitu mengecek validitas dan reliabilitas kategori coding. Tahap selanjutnya adalah analyze data yaitu peneliti menganalisis data sesuai dengan kategori pada lembar.

Adapun Tahapan-Tahapan Analisa Konten sebagai berikut :

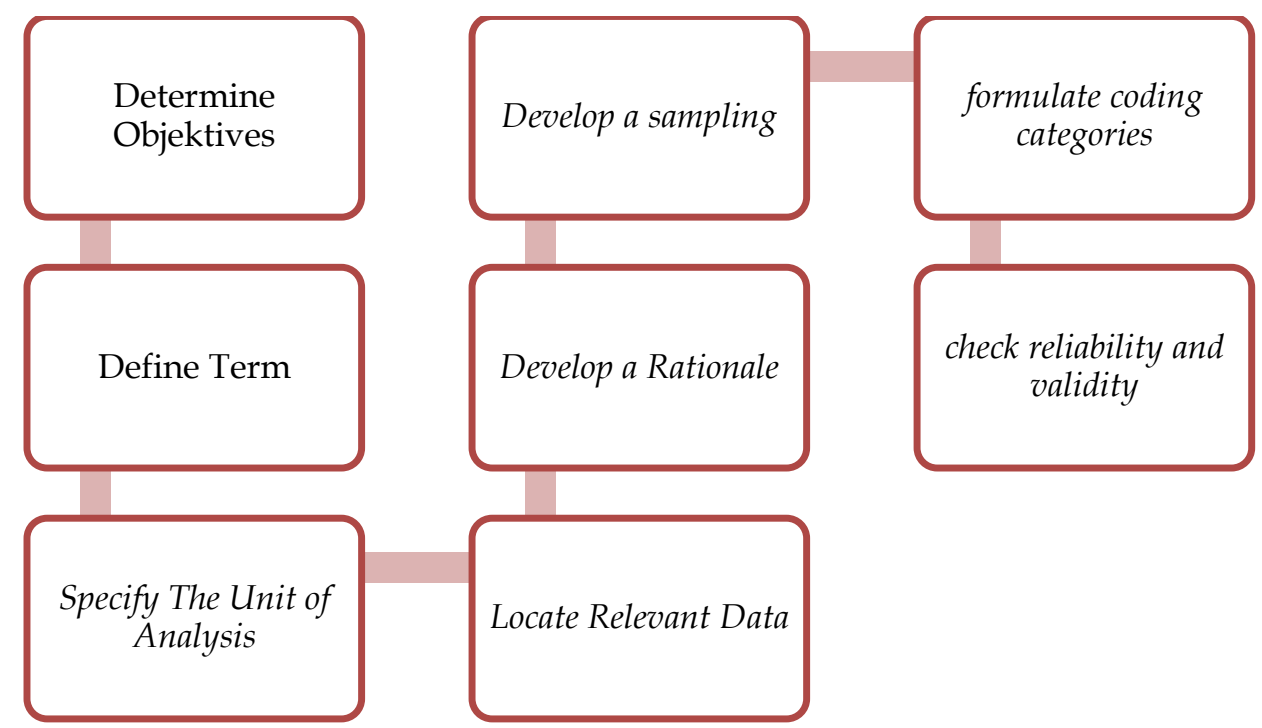

Gambar 1. Tahapan Konten Analisa.

\section{HASIL DAN PEMBAHASAN}

Memproduksi sebuah film pada umumnya mengandung pesan- pesan yang akan disampaikan kepada penontonnya. Pesan-pesan tersebut biasanya tidak hanya menggambarkan kehidupan manusia sehari-hari tetapi juga mengandung pendidikan dan nilai-nilai positif sebagai pelajaran dalam kehidupannya. Hal ini terkait dengan film sebagai miniatur sebuah adegan dalam kehidupan yang nyata. Oleh karena itu, dalam skripsi ini penulis akan memaparkan analisis pesan- pesan ajaran agama yang disampaikan melalui film Adit dan Sopo Jarwo secara sederhana yang dilihat dari aspek karakter.

Analisis pesan ajaran agama dalam film Adit dan Sopo Jarwo menggunakan analisis deskriptif dengan menggunakan perspektif dalam menafsirkan makna dengan karakter untuk memperjelas pengkategorian muatan ajaran agama dalam film Adit dan Sopo Jarwo. Adapun makna muatan ajaran agama berupa dialog, akting, visualisasi, tempat dan waktu, serta karakter pemeran setiap adegan yang disimbolkan dalam film Adit dan Sopo Jarwo, berikut ini uraiannya.

Film Adit dan Sopo Jarwo episode 21 dengan judul "Syukuran Dapat Kerjaan". Episode ini digambarkan dalam cerita bahwa setiap manusia wajib hukumnya untuk bersyukur. Salah satu sifat terpuji adalah selalu bersyukur kepada Tuhan atas segala karunia yang telah diberikan kepada kita. Syukur berasal dari kata syukuran yang berarti mengingat akan segala karuniaNya. Menurut bahasa syukur adalah suatu sifat yang penuh kebaikan dan rasa menghormati serta mengagungkan atas segala karuniaNya, baik diekspresikan dengan lisan, dimantapkan dengan hati maupun dilaksanakan melalui perbuatan. 
Untuk itu seorang yang percaya pada Tuhan, dituntut ia menyikapi kurnia Tuhan tersebut dengan bersyukur. Ia sadar bahwa karunia tersebut adalah pemberian dari Tuhan Yang Maha Kuasa, dipergunakan dalam rangka ketaatan kepada Tuhan dan tidak menyebabkan mereka sombong dan lupa kepada Yang Memberikan Karunia tersebut. Film Adit dan Sopo Jarwo episode 21 dengan judul "Syukuran Dapat Kerjaan". Episode ini digambarkan dalam cerita bahwa setiap manusia wajib hukumnya untuk bersyukur. Salah satu sifat terpuji adalah selalu bersyukur kepada Tuhan atas segala karunia yang telah diberikan kepada kita.

Syukur berasal dari kata syukuran yang berarti mengingat akan segala karuniaNya. Menurut bahasa syukur adalah suatu sifat yang penuh kebaikan dan rasa menghormati serta mengagungkan atas segala karuniaNya, baik diekspresikan dengan lisan, dimantapkan dengan hati maupun dilaksanakan melalui perbuatan.

Untuk itu seorang yang percaya pada Tuhan, dituntut ia menyikapi kurnia Tuhan tersebut dengan bersyukur. Ia sadar bahwa karunia tersebut adalah pemberian dari Tuhan Yang Maha Kuasa, dipergunakan dalam rangka ketaatan kepada Tuhan dan tidak menyebabkan mereka sombong dan lupa kepada Yang Memberikan Karunia tersebut.

Pesan lain yang berkaitan dengan kepercayaan atau keyakinan yaitu pesan pedagogies diperintahkan untuk memohon kepada Tuhan tergambar dalam adegan ketika Haji Udin memimpin doa atas syukur diterimanya Bang Jarwo bekerja di kantor. Doa tersebut dapat dipahami bahwa segala yang kita miliki adalah kehendakNya dengan begitu kita dituntut untuk berserah diri dan taat dengan segala perintah dan laranganNya.

Hal tersebut dapat diartikan bahwa bukan berarti hanya orang-orang yang sedang ditimpa musibah saja yang layak memanjatkan doa. Dalam keadaan segar-bugar dan tidak kekurangan suatu apapun, sebagai manusia kiranya kita layak berdoa. Setidaknya kita berdoa memohon kepada Allah untuk mengampuni segala dosa-dosa, baik yang kita sengaja maupun tidak. Juga meminta tetap diberi kekuatan iman dan kesehatan agar dapat melaksanakan segala perintahNya. Lalu memohon perlindunganNya dari segala gangguan dan hal-hal yang tidak baik.

Berkaitan dengan bidang akhlak yang termuat di dalam film Adit dan Sopo Jarwo pada episode ini yaitu: Seseorang yang sabar dan selalu berusaha dengan kerja keras akan membuahkan hasil yang tak terduga, karena Tuhan akan membalas jerih payahnya itu melebihi keinginannya. Sabar ini tergambar dari sosok Bang Jarwo yang sabar, kerja keras dan ikhlas. "Pada dasarnya hidup itu bukan untuk berdiam diri, tetapi untuk dapat meraih yang kita inginkan perlu adanya kerja keras, keikhlasan dan kesabaran" itulah kata-kata yang disampaikan bang Jarwo ketika mengadakan syukuran.

Sabar merupakan wakil dari mengenai sifat dan karakter orang yang beriman. Karena sifat dan karakter ini akan mempesona siapa saja. Sifat positif, dapat memandang segala persoalannya dari sudut pandang positif, dan bukan dari sudut negatifnya.

Pesan pedagogies yang berkaitan dengan membina hubungan dengan orang lain yaitu kebersamaan dan tolong menolong. Adegan saat Bang Jarwo mengundang anak-anak di Kampung Karet untuk menghadiri syukuran yang diadakan Bang Jarwo. Terlihat kebersamaan dan rukun warga Kampung Karet walaupun ada yang berebut hidangan yang disediakan, dalam hal ini Bang Jarwo bermaksud untuk meminta doa dan mendapatkan berkah atas pekerjaan yang diterima Bang Jarwo. Sedangkan pada segi tolong menolong tergambar ketika Adit, Denis dan teman-temannya bermain di lapangan. Pada waktu giliran Denis yang melakukannya dia terjatuh dan serentak teman-temannya datang membantu.

\section{Cara Menanamkan Nilai-Nilai Karakter dalam film Adit Sopo Jarwo}

Penanaman nilai-nilai karakter kepada warga sekolah yang meliputi komponen pengetahuan, kesadaran atau kemauan, dan tindakan untuk melaksanakan nilai-nilai tersebut, baik terhadap Tuhan Yang Maha Esa (YME), diri sendiri, sesama, lingkungan, maupun kebangsaan. bentuk-bentuk penanaman nilai-nilai karakter yang terdiri dari 
pengajaran, pembiasaan, peneladanan, pemotivasian dan penegakan aturan. Selanjutnya, proses pendidikan karakter harus dilibatkan semua komponen (stakeholders).

Penanaman karakter yang dilakukan pada film Adit dan Sopo Jarwo melalui pemberitahuan nilai-nilai karakter tentang sikap sabar dan pekerja yang disampaikan oleh Bang Jarwo Sabar ini tergambar dari sosok Bang Jarwo yang sabar, kerja keras dan ikhlas. "Pada dasarnya hidup itu bukan untuk berdiam diri, tetapi untuk dapat meraih yang kita inginkan perlu adanya kerja keras, keikhlasan dan kesabaran" itulah kata-kata yang disampaikan bang Jarwo ketika mengadakan syukuran. Hal ini sejalan dengan yang disampaikan oleh Thomas Lichona bahwa salah satu cara yang dapat digunakan untuk menanamkan moral/karakter yaitu dengan cara memberikan pengetahuan kepada objek. Pendidikan karakter harus melibatkan kognitif (pengetahuan) agar anak mau melakukan karakter (Baginda, 2018)

Penanaman karakter yaitu melalui moral feeling misalnya Sopo sangat bersyukur karena Jarwo memberikan pekerjaan itu untuknya, sehingga Sopo dengan mengucap hamdalah "Alhamdulillah..." dan merasa senang telah mendapatkan pekerjaan. Alhamdulillah merupakan ungkapan perasaan yang dirasakan oleh Sopo mengajarkan untuk mengungkapkan perasaan yang dirasakan (Thomas Lickona, 2012). Feeling the good diharapkan menjadi mesin penggerak sehingga seseorang secara suka reka melakukan perbuatan yang baik (acting the good). Penanaman dengan model seperti itu, akan mengantarkan seseorang kepada kebiasaan berlaku baik (Baginda, 2018)

Metode yang digunakan berikutnya adalah melalui metode keteladanan sebagaimana kutipan episode 23 yang dilakukan oleh Darwis misalnya : “Darwis : Oke..Oke.. bentar ya. Nuwun sewu nggak bisa lama ni disininya. tapi ini, monggo insyaallah bisa jadi berkah nggeh. Monggo semua, saya tak permisi dulu nggeh, pareng pareng sedoyo nggeh. Assalamualaikum".

Hal yang dilakukan darwis dengan memberikan sesuatu kepada temannya adalah bentuk moral action yang dilakukan melalui keteladanannya. Anak usia dini pada perkembangan moralnya mampu menirukan apa yang ada dilingkungan (Masithoh, 2018). Secara tidak langsung anak merekam apa yang dilihat kemudian meniru perilaku yang dilakukan oleh Darwis dan diterapkan pada kehidupan sehari-hari.

Selanjutnya adalah metode hukuman hal ini terlihat pada percakapan dalam episode 24 saat Jarwo mencoba untuk bertindak tidak jujur. Adapun percakapannya sebagai berikut: "H. Udin: Hmm... ini diye nih yang ane kagak demen. Ente gimana sih wo', yang kayak gitu ntu kagak ada berkahnya. Kan udah ane bilang, sunatan masalnya gratis."

Hukuman adalah reiforcement yang negatif, tetapi diperlukan dalam pendidikan (Sudarto, 2017). Hukuman diperlukan untuk membuat anak usia dini membiasakan perilakuperilaku baik sehingga akan menjadi kebiasaan dalam kehidupan sehari-hari. Hukuman dapat berupa kata-kata maupun Tindakan. Hukuman presentasi. Penggunaan konsekuensi yang tidak menyenangkan, atau rangsangan permusuhan, mencirikan hukuman presentasi, seperti ketika seorang siswa dimarahi. Hukuman penghapusan. Penarikan konsekuensi yang menyenangkan menggambarkan hukuman penghapusan . Contohnya termasuk kehilangan hak istimewa, harus tinggal selama istirahat, dan menerima penahanan setelah sekolah.

\section{Relevansi Film Adit dan Sopo Jarwo dalam Menanamkan Nilai-Nilai Karakter Jika Ditinjau Dari Aspek Sosiopedagogiek}

Film Adit dan Sopo Jarwo menuntun anak yang membicarakan masalah atau persoalan-persoalan dalam pendidikan dan kegiatan-kegiatan mendidik tentang mengajarkan nilai-nilai karakter pada anak usia dini. Aktivitas pedagogiek yang terdapat dalam film yaitu proses atau aktifitas yang bertujuan agar tingkah laku manusia mengalami perubahan.

Nilai-nilai pendidikan karakter yang ada film tersebut diantaranya sikap religious, sopan santun, jujur, tolong menolong, saling menghormati dan menyayangi, tanggung jawab dan bersikap hati-hati. Nilai-nilai tersebut tercermin dalam setiap scene film Adit dan Sopo Jarwo. Nilai-nilai karakter tersebut disampaikan melalui metode keteladanan dan ceramah. 
Terdapat deskripsi cerita berikut ini Adegan saat Bang Jarwo mengundang anak-anak di kampung karet untuk menghadiri syukuran yang diadakan Bang Jarwo. Terlihat kebersamaan dan rukun warga kampung karet walaupun ada yang berebut hidangan yang disediakan, dalam hal ini Bang Jarwo bermaksud untuk meminta doa dan mendapatkan berkah diterimanya kerja Bang Jarwo.

Pada potongan deskripsi cerita tersebut menjelaskan bahwa membangun sikap rukun dan kebersamaan diperlukan keteladanan yang keteladanan itu disampaikan dalam konten film Adit dan Sopo Jarwo. Hal tersebut mengambarkan pelaksanaan pembelajaran yang mendidik bagi penonton.

Adegan lain juga disampaikan dalam scene yaitu pada saat Adit, Denis dan temantemannya bermain di lapangan. Pada waktu giliran Denis yang melakukannya dia terjatuh dan serentak teman-temannya datang membantu. Film ini mengajak kepada penonton untuk memiliki sikap tolong menolong. Sikap tolong menolong merupakan salah satu ciri dari nilainilai pendidikan karakter yakni sikap peduli (Rafika Bayu Kusumandari, 2013).

Sikap dermawan tercermin pada kepribadian Jarwis yang baik hati dan dermawan kepada saudaranya, yaitu dengan memberikan sedikit rejekinya untuk Jarwo. Memang tidak seberapa tetapi semoga berkah itulah kata Jarwis untuk Bang Jarwo. “Jarwis : Oke..Oke.. bentar ya. Nuwun sewu nggak bisa lama ni disininya. tapi ini, monggo insyaallah bisa jadi berkah nggeh. Monggo semua, saya tak permisi dulu nggeh, pareng pareng sedoyo nggeh. Assalamualaikum".

Sikap dermawan ini termasuk sikap kasih karena menunjukan sikap empati kepada orang lain dengan membagikan rejeki kepada orang lain (Thomas Lickona, 2012). Sikap dermawan ini juga relevan dengan sikap peduli sosial yang merupakan salah satu pilar-pilar nilai karakter (Pasrah et al., 2020)

\section{Faktor-Faktor yang mendukung penanaman pendidikan karakter dalam Film Adit dan Sopo Jarwo}

Perkembangan karakter pada setiap individu dipengaruhi oleh faktor bawaan (nature) dan faktor lingkungan (nurture). Menurut para developmental psychologist, setiap manusia memiliki potensi bawaan yang akan termanisfestasi setelah dia dilahirkan, termasuk potensi yang terkait dengan karakter atau nilai-nilai kebajikan (Yuniarni, 2012). Cina menyatakan bahwa manusia pada dasarnya memiliki potensi mencintai kebajikan, namun bila potensi ini tidak diikuti dengan pendidikan dan sosialisasi setelah manusia dilahirkan, maka manusia dapat berubah menjadi binatang, bahkan lebih buruk lagi.

Pada film Adit dan Sopo Jarwo pendidikan karakter dipengaruhi oleh masyarakat atau lingkungan dan keluarga. Pada scene episode 22 terdeskripsi ketika Adit dan Dennis hendak pergi mengantar kue, mereka mencium tangan orangtua, memiliki arti atau pemahaman bahwa hal tersebut untuk menghormati dan menyayangi beliau yang telah banyak memberikan kebaikannya tanpa pamrih. Dalam film ini diajarkan bahwa budaya keluarga akan mempengaruhi perilaku anak.

Disamping itu film Adit dan Sopo Jarwo ini mengajarkan bahwa lingkungan dapat mempengaruhi pembelajaran nilai-nilai karakter contohnya pada episode 24 saat pak Haji Menegur Jarwo bahwa yang dilakukan Bang Jarwo salah, dan tidak ada berkah atau manfaatnya. "H. Udin: Hmm... ini diye nih yang ane kagak demen. Ente gimana sih wo', yang kayak gitu ntu kagak ada berkahnya. Kan udah ane bilang, sunatan masalnya gratis".

Pendidikan yang berlangsung memasukkan pendidikan karakter sebagai salah satu tujuan pembelajaran. Hal ini tidak terlepas dari pengaruh lingkungan keluarga yang tidak harmonis. Lingkungan sekolah merupakan lingkungan berkarakter di, karena di sekolah seorang anak mendapatkan pengetahuan pendidikan karakter seorang anak. Pengaruh lingkungan masyarakat sangat dominan mempengaruhi karakter seorang anak, karena di masyarakatlah anak berkembang (Megawangi, 2004). Walaupun seorang anak itu dilahirkan di keluarga baik-baik atau berpendidikan yang baik namun jika dimasukkan di dalam 
lingkungan yang kurang baik, anak itu akan menjadi kurang baik atau tidak berkarakter sama sekali. Jadi berdasarkan pendapat di atas dapat disimpulkan bahwa lingkungan keluarga, lingkungan sekolah dan lingkungan masyarakat secara bersamaan menentukan keberhasilan pendidikan karakter.

Sosialisasi dan pendidikan anak yang berkaitan dengan nilai-nilai kebajikan - baik di keluarga, sekolah, maupun masyarakat. Karakter merupakan kualitas moral dan mental seseorang yang pembentukannya dipengaruhi oleh faktor bawaan (fitrah-nature) dan lingkungan (sosialisasi atau pendikan-nurture). Potensi karakter yang baik dimiliki manusia sebelum dilahirkan, tetapi potensi tersebut harus terus-menerus dibina melalui sosialisasi dan pendidikan sejak usia dini. Anak-anak akan tumbuh menjadi pribadi yang berkarakter apabila dapat tumbuh pada lingkungan yang berkarakter, sehingga fitrah setiap anak yang dilahirkan suci dapat berkembang segara optimal. Mengingat lingkungan anak bukan saja lingkungan keluarga yang sifatnya mikro, maka semua pihak-keluarga, sekolah, media massa, komunitas bisnis, dan sebagainya-turut andil dalam perkembangan karakter anak. Dengan kata lain, mengembangkan generasi penerus bangsa yang berkarakter baik adalah tanggung jawab semua pihak (Suarto, 2017).

Orang tua dan lingkungan sektar memiliki peran besar dalam mendidik karakter anak sebagaimana yang dilakukan oleh keluarga adit dan pak haji kepada masyarakat hal ini sejalan dengan pendapat Langeveld sampai pada tindakan orang tua dan pendidik. Pola asuh adalah apa yang terjadi dalam interaksi antara orang dewasa dan anak-anak, dan pengaruh dilakukan selama interaksi tersebut. Dalam hal pengasuhan, arah pengaruhnya adalah dari orang dewasa ke anak. Pengaruh tersebut memiliki tujuan, yaitu orang dewasa mengambil tindakan yang disengaja untuk mencapai tujuan pengasuhan. Inti dari hubungan antara pengasuh dan anak yang dibesarkan adalah hubungan otoritas. Kewenangan ini didefinisikan sebagai tanggung jawab moral dan kewajiban untuk kepentingan anak di bawah umur. Jelas otoritas orang tua bertujuan untuk secara bertahap menghapus dirinya sendiri: kemandirian anak yang tumbuh adalah pelengkap. Itulah yang menentukan batas atas pengasuhan: ketika anak yang dibesarkan menjadi dewasa. Wewenang secara teknis diperlukan dalam pengasuhan (Levering, 2012)

\section{SIMPULAN}

Dari hasil penelitian diatas dapat disimpulkan bahwa film Adit dan Sopo Jarwo dengan sample episode 21-24 mengandung nilai-nilai karakter jika ditinjau dari aspek pedagogies diantaranya nilai karakter menjaga hubungan dengan Tuhan dan sesama yang didalamnya terkandung sifat sopan santun, jujur, saling menghormati, saling menyayangi dan disiplin.

\section{UCAPAN TERIMA KASIH}

Terimakasih kepada pembimbing yang sudah membantu memberikan masukan pada penelitian ini.

\section{DAFTAR PUSTAKA}

Agung, P., \& Asmira, Y. D. (2018). Pengembangan Model Pendidikan Karakter Peduli Sosial Melalui Metode Bermain Peran Di Tk Tunas Mekar Indonesia Bandar Lampung. Jurnal Caksana: Pendidikan Anak Usia Dini, 1(02), 139-158. https://doi.org/10.31326/jcpaud.v1i02.195

Baginda, M. (2018). Nilai-Nilai Pendidikan Berbasis Karakter pada Pendidikan Dasar dan Menengah. Jurnal Ilmiah Iqra', 10(2), 1-12. https:/ / doi.org/10.30984/jii.v10i2.593

Devianti, R., Sari, S. L., \& Bangsawan, I. (2020). Pendidikan Karakter untuk Anak Usia Dini. MITRA ASH-SHIBYAN: Jurnal Pendidikan Dan Konseling, 3(02), 67-78. https://doi.org/10.46963/mash.v3i02.150 
Kabadayi, L. (2012). The Role of Short Film in Education. Procedia - Social and Behavioral Sciences, 47, 316-320. https:// doi.org/10.1016/j.sbspro.2012.06.657

Khakim, A. A. Al, \& Sofiana, D. A. A. W. (2019). Pemilihan Film Anak Dan Kaitannya. 150-160.

Latifatul Masruroh. (2020). Identifikasi nilai karakter pada anak usia dini di paud cikal karangampel. Alfikar Journal For Islamic Studies, 3(2), 23-28.

Levering, B. (2012). Martinus Jan Langeveld: Modern Educationalist of Everyday Upbringing. In Education and the Kyoto School of Philosophy (pp. 133-146). Springer Netherlands. https://doi.org/10.1007/978-94-007-4047-1_10

Masithoh, D. (2018). Teachers' scientific approach implementation in inculcating the students' scientific attitudes. Jurnal Prima Edukasia, 6(1), 32-43. https:// doi.org/10.21831/jpe.v6i1.14282

Megawangi, R. (2004). Pendidikan yang Patut dan Menyenangkan: Penerapan Teori Developmentally Appropriate Pracices (DAP) Anak-anak Usia Dini 0 sampai 8 tahun. In Cimanggis: Indonesia Heritage Foundation. Indonesia Heritage Foundation.

Nuraeni. (2014). Pendidikan Karakter Pada Anak Usia Dini. Jurnal Paedagogy, 1(2).

Nyoman, A. F. dan N. N. S. (2003). Penanaman Nilai-Nilai Karakter Anak Usia Dini dengan Pendekatan SHIP (Issue 1). https:/ / doi.org/10.16309/j.cnki.issn.1007-1776.2003.03.004

Pasrah, R., Ganda, N., \& Mulyadiprana, A. (2020). Nilai-Nilai Karakter yang Terdapat dalam Film Animasi Upin dan Ipin Episode "Jembatan Ilmu." PEDADIDAKTIKA: Jurnal Ilmiah Pendidikan Guru Sekolah Dasar, 7(3), 152-164.

Pratama, F. F. (2020). Membangun Karakter Siswa Melalui Penggunaan Media Pembelajaran Scrabble Games. Academy of Education Journal, 11(2), 129-141. https:// doi.org/10.47200/aoej.v11i2.397

Rafika Bayu Kusumandari. (2013). Character Education Model For Early Chilhood Based On E-Learning And Culture Of Java. Indonesian Journal of Early Childhood Education Studies, 2(1). https://doi.org/10.15294/ijeces.v2i1.9251

Sadiman, A. S., \& Dkk. (1990). Media Pendidikan. Rajawali Pers.

Samani, \& Hariyanto, M. (2011). Konsep dan Model Pendidikan Berkarakter. PT. Remaja Rosdakarya.

Suarto, E. (2017). Faktor-faktor yang mempengaruhi dalam penanaman pendidikan karakter di sekolah tingkat pertama di kota padang. Jurnal Manajemen Pendidikan, 2(1), 261-276. https:// doi.org/10.34125/mp.v2i1.139

Sudarto, S. (2017). Implementasi Metode Targhib dan Tarhib dalam Pembelajaran Akidah Akhlak Peserta Didik Mts Hidayatus Syubban Karangroto Genuk Semarang. Waspada (Jurnal Wawasan Pengembangan Pendidikan), 2(2), 36-54.

Sugiyono. (2007). Metode Penelitian Kuantitatif, Kualitatif dan RED. Alfabeta.

Sukenti, D. (2011). Media Pembelajaran (Strategi dan Aplikasi Program Media Pembelajaran di Perguruan Tinggi). STIKIP Aisyiah Riau.

Thomas Lickona. (2012). Persoalan Karakter: Bagaimana Membantu Anak Mengembangka $n$ Penilaian yang Baik, Integritas, dan Kebajikan Penting Lainnya (p. 183). Bumi Aksara.

Yuniarni, D. (2012). Character Education in Early Childhood. Jurnal Visi Ilmu Pendidikan, 7(1), 29-42. https://doi.org/10.26418/jvip.v7i1.333

Zhayoga, I., H, D. E., \& Listyarini, I. (2020). Analisis Pengaruh Film Upin dan Ipin Terhadap Karakter Siswa. Indonesian Values and Character Educational Journal, 3(1), 1-7. https:// ejournal.undiksha.ac.id/index.php/IVCEJ/article/view/24542/14886 